\title{
PERSEPSI SISWA SMA NEGERI 3 MALANG TERHADAP PROFIL GURU PENDIDIKAN JASMANI, OLAHRAGA DAN KESEHATAN
}

\author{
Sutiono $^{1}$, Siti Nurrochmah ${ }^{2}$, Sapto Adi ${ }^{3}$
}

SMA Negeri 7 Malang

\begin{abstract}
Info Artikel
Sejarah Artikel:

Diterima Desember 2017

Disetujui April 2018

Dipublikasikan Agustus 2018

\section{Keywords:}

Persepsi, Profil Guru,

Pendidikan Jasmani.

Abstrak

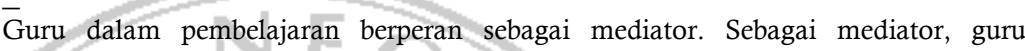
pendidikan jasmani, olahraga dan kesehatan dituntut untuk mengetahui persepsi siswa agar pembelajaran berlangsung menyenangkan. Oleh sebab itu, diadakan penelitian yang bertujuan mengetahui persepsi siswa terhadap profil guru pendidikan jasmani, olahraga dan kesehatan dengan menggunakan rancangan penelitian deskriptif. Populasi dalam penelitian ini adalah siswa SMA Negeri 3 Malang yang berjumlah 816 orang siswa dan diambil $25 \%$ atau 216 orang siswa sebagai sampel penelitian dengan menggunakan teknik stratified purposive propotional systematic random sampling. Hasil yang diperoleh dalam penelitian ini menyatakan bahwa persepsi siswa terhadap profil guru pendidikan jasmani, olahraga dan kesehatan adalah berbadan ideal, energik, rapi, disiplin, tanggung jawab, dekat dan memahami siswa, mengerti, paham dan terampil dalam olahraga dan pengetahuan kesehatan.

Abstract

Teachers in learning act as mediators. As a mediator, physical education, sports and health teachers are required to know students' perceptions so that learning takes place pleasantly. Therefore, a study was conducted aimed at knowing students' perceptions of the profile of physical education, sports and health teachers by using a descriptive research design. The population in this study were students of SMA Negeri 3 Malang, amounting to 816 students and taken $25 \%$ or 216 students as the research sample using the stratified purposive technique proportional systematic random sampling. The results obtained in this study state that students' perceptions of the profile of physical education, sports and health teachers are ideal, energetic, neat, disciplined, responsible, close and understand students, understand, understand and are skilled in sports and health knowledge.
\end{abstract}

(C) 2018 Universitas Negeri Malang

$凶$ Alamat korespondensi:

ISSN 2614-8293 (Online)

E-mail: bayusutiono07@yahoo.com

\section{PENDAHULUAN}

Dalam lembaga pendidikan (Sekolah), terdapat lima komponen yang mempengaruhi baik atau buruknya kualitas sekolah tersebut. Komponen-komponen tersebut yaitu konteks, masukan, proses, keluaran, dan hasil (Suparlan, 2005:60). Dari keseluruhan komponen yang ada pada sekolah, ada tiga subkomponen utama dari masukan yaitu guru, peserta didik, dan kurikulum. Dari ketiga subkomponen utama tersebut, guru merupakan salah satu 
subkomponen yang memiliki peran penting dalam pembelajaran.

Peran penting dan vital seorang guru tersebut seperti yang diungkapkan oleh Bapak Pendidikan kita Ki Hajar Dewantara yang berbunyi "Ing ngarso sung tulodho, Ing madyo mangun karso, dan Tut wuri handayani" yang berarti bahwa guru dari depan sebagai contoh, dari tengah sebagai pemberi semangat dan dari belakang sebagai pendorong semangat belajar siswa-siswanya (Soelaiman, 1985:89). Untuk dapat menjalankan peran tersebut, seorang guru harus senantiasa memahami persepsi siswa terhadap sosok guru secara umum atau biasa disebut sebagai profil guru. Persepsi adalah tanggapan yang diungkapkan secara langsung tentang sesuatu (Tim Penyusun Kamus Pusat Bahasa, 2002:863). Sedangkan Profil adalah gambaran umum tentang suatu obyek yang dilengkapi dengan sejumlah informasi tertentu (Sondita dan Burhanudin, 2000:xii).

Guru adalah pegawai negeri sipil yang diberi tugas, wewenang, dan tanggung jawab oleh pejabat yang berwenang untuk melaksanakan pendidikan di sekolah (Suparlan, 2005:15). Sedangkan siswa menurut Aminuddin (dalam Adrian, 2004:6), merupakan seseorang atau sekelompok orang yang bertindak sebagai pelaku pencari, penerima dan penyimpan isi pelajaran yang dibutuhkannya untuk mencapai tujuan. Guru dan siswa merupakan dua komponen yang mempengaruhi kualitas suatu sekolah. Guru dan siswa diharapkan memiliki hubungan baik dan saling memahami demi tercapainya tujuan dan meningkatkan kualitas sekolah secara khusus dan kualitas pendidikan nasional secara umum. Salah satu cara bagi guru untuk memahami siswa adalah dengan mengetahui persepsi siswa terhadap profil seorang guru.

Dalam pendidikan jasmani, olahraga dan kesehatan, hal tersebut merupakan suatu masalah yang menarik untuk dibahas dan dikaji dalam suatu penelitian karena jarang diperhatikan dan dianggap sepele. Selain itu, masih sulit dijumpai adanya guru pendidikan jasmani, olahraga dan kesehatan di sekeliling kita yang kompeten dan sukses mengelola mata pelajarannya, sehingga siswa menyukai, menghargai dan bersungguh-sungguh dalam mengikuti proses pembelajaran dan mengimbas ke pola hidup aktif dan sehat dalam kehidupan sehari-hari (Tim Peneliti Balitbang Diknas, 2008:4).

Sesuai dengan penjelasan pada paragraf sebelumnya, maka penulis melakukan penelitian yang membahas tentang persepsi siswa SMA Negeri 3 Malang terhadap profil guru pendidikan jasmani, olahraga dan kesehatan tahun ajaran 2008/2009. Sedangkan tujuan penelitian ini adalah untuk menggambarkan atau mendeskripsikan persepsi siswa SMA Negeri 3 Malang terhadap profil guru pendidikan jasmani, olahraga dan kesehatan tahun ajaran 2008/2009.

\section{METODE}

Penelitian ini menggunakan rancangan deskriptif dan variabel yang diteliti berupa persepsi siswa sma negeri 3 malang terhadap profil guru pendidikan jasmani, olahraga dan kesehatan tahun ajaran 2008/2009. Variabel tersebut dibagi menjadi beberapa sub-variabel yaitu aspek fisik, moral, hubungan sosial, kemampuan olahraga dan pengetahuan kesehatan.

Populasi dalam penelitian ini adalah siswa SMA Negeri 3 Malang berjumlah 826 orang siswa dan diambil 216 orang siswa sebagai sampel penelitian yang diambil sebesar $25 \%$ dari jumlah populasi siswa SMA Negeri 3 Malang dengan menggunakan teknik stratified purposive propotional random sampling (Arikunto, 2006:137141). Instrumen penelitian yang digunakan adalah instrumen non-tes berupa angket. Angket yang digunakan dalam penelitian ini adalah angket semi terbuka dengan satu pilihan jawaban kosong. Angket yang digunakan terlebih dahulu diuji cobakan kepada responden yang memiliki karakteristik mendekati sama dengan subyek penelitian. Hasil dari uji coba angket menyatakan bahwa angket dalam penelitian ini telah memenuhi syarat sebagai intrumen penelitian yaitu syarat validita dan reliabilita. Pengumpulan data menggunakan teknik angket yang disebarkan kepada responden. Data yang terkumpul selanjutnya dianalisis menggunakan statistika deskriptif dengan menghitung persentase dari jawaban responden.

\section{HASIL}

Hasil dari penelitian ini dijabarkan secara singkat dan diambil dari jawaban terbesar untuk tiap butir angket. Penjabaran dari hasil penelitian dibagi menjadi lima yaitu aspek fisik, moral, hubungan sosial, kemampuan olahraga dan pengetahuan kesehatan.

Dari aspek fisik dan moral, diperoleh hasil yang menyatakan bahwa seorang guru pendidikan jasmani, olahraga dan kesehatan berbadan ideal (tinggi badan-110=berat badan) 
(146 orang siswa/67,59\%), senantiasa aktif bergerak (energik) (172 orang siswa/79,63\%), senantiasa rapi dan sesuai dalam berpenampilan (167 orang siswa/77,31\%), dan memiliki suara sesuai dengan situasi dan kondisi pembelajaran (171 orang siswa/79,16\%), senantiasa tepat waktu dalam segala aktivitas (disiplin waktu) (181 orang siswa/83,79\%) dan memberikan penilaian dan hukuman secara adil sesuai kemampuan dan kesalahan siswa (obyektif) (164 orang siswa/75,92\%), menyusun rencana pembelajaran sesuai dengan kurikulum (tanggung jawab terhadap tugas) (142 orang siswa/65,74\%) dan senantiasa mengawasi semua siswanya selama proses pembelajaran berlangsung (tanggung jawab terhadap siswa) (176 orang siswa/81,48\%).

Dari aspek hubungan sosial dan kemampuan olahraga, diperoleh hasil yang menyatakan seorang guru pendidikan jasmani, olahraga dan kesehatan melakukan pendekatan dengan semua siswa sama baiknya (170 orang siswa/78,71\%) dan senantiasa berusaha untuk memahami semua masalah yang dihadapi siswa (169 orang siswa/78,25\%), mengerti, memahami, dan menguasai semua teknik permainan dalam olahraga (120 orang siswa/55,56\%), senantiasa mampu menjelaskan dan memberikan contoh berbagai keterampilan atletik kepada siswa (157 orang siswa/72,68\%), senantiasa mampu menjelaskan dan memberikan contoh berbagai keterampilan yang ada pada olahraga beregu kepada siswa (156 orang siswa/72,22\%), dan mampu menjelaskan dan memberikan contoh berbagai keterampilan yang ada pada olahraga perorangan kepada siswa (162 orang siswa/75\%).

Sedangkan dari aspek pengetahuan kesehatan, hasil dari penelitian menyatakan bahwa seorang guru pendidikan jasmani, olahraga dan kesehatan adalah mengetahui dan mampu memberikan pertolongan pertama pada siswa yang mengalami kecelakaan pada waktu pembelajaran dengan cepat dan tepat (163 orang siswa $/ 75,46 \%)$, senantiasa menganjurkan siswa dan menjalani pola hidup sehat (134 orang siswa/62,04\%), dan senantiasa mengajarkan dan mengajak siswa untuk menjaga lingkungan dengan baik (134 orang siswa/62,04\%).

\section{PEMBAHASAN}

Hasil penelitian yang berkenaan dengan aspek fisik menyatakan bahwa guru pendidikan jasmani, olahraga dan kesehatan adalah berbadan ideal, senantiasa aktif bergerak (energik), senantiasa rapi dan sesuai dalam berpenampilan, dan memiliki suara sesuai dengan situasi dan kondisi pembelajaran. Hal ini didukung oleh tendencia (dalam suparlan, 2005:121-124) yang menjelaskan karakteristik guru secara umum yaitu memberikan contoh cara berpakaian yang baik, berperawakan menarik, kemas dan bersuara lunak (wanita), serta aktif dan bersemangat. Selain itu, rokhmatika (1998:56), mengemukakan bahwa seorang guru pendidikan jasmani, olahraga dan kesehatan berbadan ideal, senantiasa menggunakan pakaian dan sepatu olahraga pada waktu mengajar, energik, memiliki roman muka ceria, dan memiliki suara yang enak didengar (tidak terlalu keras dan tidak terlalu pelan). Berdasarkan pada hasil penelitian, pendapat ahli, dan penelitian sebelumnya yang telah dijabarkan di atas, tidak dapat dipungkiri bahwa seorang guru pendidikan jasmani, olahraga dan kesehatan yang sesuai dengan persepsi siswa adalah memiliki penampakan badan ideal, aktif bergerak, berpenampilan rapi, dam bisa menyesuaikan suaranya sesuai situasi. Hasil penelitian yang berkenaan dengan aspek moral menyatakan bahwa guru pendidikan jasmani, olahraga dan kesehatan adalah dari segi disiplin senantiasa tepat waktu dalam segala aktivitas dan memberikan penilaian dan hukuman secara adil sesuai kemampuan dan kesalahan siswa (obyektif). Sedangkan untuk segi tanggung jawab, guru pendidikan jasmani, olahraga dan kesehatan menyusun rencana pembelajaran sesuai dengan kurikulum dan senantiasa mengawasi semua siswanya selama proses pembelajaran berlangsung. Hal ini didukung oleh hart (dalam suparlan, 2005:123) yang menyebutkan beberapa karakteristik guru yaitu tegas dan cakap mengawal kelasnya, adil, dan tidak pilih kasih. Sedangkan lewis (2004: 36), menyebutkan bahwa ciri-ciri guru yang baik yaitu dapat menjaga agar pembelajaran tetap berjalan, menjaga siswa tetap tertarik mengikuti pembelajaran, menjaga siswa tetap bertanggung jawab, dan membuat siswa merasa dimonitori. Berdasarkan pada pendapat tersebut seorang guru pendidikan jasmani, olahraga dan kesehatan senantiasa tegas, adil, bertanggung jawab, dan senantiasa mengawasi siswanya dengan baik.

Hasil penelitian yang berkenaan dengan aspek hubungan sosial menyatakan bahwa guru pendidikan jasmani, olahraga dan kesehatan adalah melakukan pendekatan dengan semua siswa sama baiknya dan senantiasa berusaha untuk memahami semua masalah yang dihadapi siswa. Jama'ah (dalam suparlan, 2005:121) menyebutkan bahwa guru harus adil dan 
memandang sama rata siswa serta mempunyai pemahaman yang baik tentang aspek kualiti individu dan kemampuan siswa. Seorang guru sebaiknya senantiasa mendengarkan setiap keluhan siswa yang datang padanya dan mengarahkannya dalam penyelesaian masalah tersebut atau dengan kata lain bertindak sebagai penasihat (walgito, 2004:67). Berdasarkan hasil penelitian dan pendapat beberapa ahli di atas, jelas bahwa seorang guru pendidikan jasmani, olahraga dan kesehatan adalah senantiasa menjaga hubungan baik dengan siswa. Beberapa cara yang bisa ditempuh yaitu dengan berusaha untuk selalu dekat dengan siswa, berusaha memahami masalah siswa, dan senantiasa membimbing siswa dalam menyelesaikan segala permasalahan yang dihadapi oleh siswa.

Hasil penelitian yang berkenaan dengan aspek kemampuan olahraga menyatakan bahwa guru pendidikan jasmani, olahraga, dan kesehatan adalah mengerti, memahami, dan menguasai semua teknik permainan dalam olahraga, senantiasa mampu menjelaskan dan memberikan contoh berbagai keterampilan atletik kepada siswa, senantiasa mampu menjelaskan dan memberikan contoh berbagai keterampilan yang ada pada olahraga beregu kepada siswa, dan mampu menjelaskan dan memberikan contoh berbagai keterampilan yang ada pada olahraga perorangan kepada siswa. Bucher (dalam wirjosantosa, 1984:190) mengatakan bahwa "seorang guru pendidikan jasmani, olahraga dan kesehatan masih juga dituntut ketangkasan pribadinya untuk mampu mengajar berbagai permainan dan kegiatankegiatan olahraga lainnya yang penting sesuai dengan keperluannya". Selain itu, dalam standar kompetensi dan sertifikasi guru (mulyasa, 2007: 138) disebutkan bahwa salah satu kompetensi yang harus dimiliki oleh seorang guru adalah kompetensi profesional yaitu guru dituntut untuk memahami profesinya dan mampu menyusun serta merancang pembelajaran yang sesuai dengan kebutuhan siswa. Sebagai seorang guru pendidikan jasmani, olahraga dan kesehatan, tidak dapat dipungkiri bahwa seseorang tersebut harus memiliki keterampilan yang baik dalam berbagai macam aktivitas fisik seperti keterampilan dalam beberapa bidang olahraga. Berdasarkan hasil penelitian dan pendapat beberapa ahli di atas, jelas bahwa seorang guru pendidikan jasmani, olahraga, dan kesehatan diharapkan untuk senantiasa belajar dan meningkatkan keterampilannya dalam bidang ilmu olahraga. Hal ini diharapkan ada pada setiap guru pendidikan jasmani, olahraga, dan kesehatan karena olahraga merupakan bidang ilmu yang media pembelajarannya sebagian besar menggunakan aktifitas fisik.

Hasil penelitian yang berkenaan dengan aspek pengetahuan kesehatan menyatakan bahwa guru pendidikan jasmani, olahraga dan kesehatan adalah mengetahui dan mampu memberikan pertolongan pertama pada siswa yang mengalami kecelakaan pada waktu pembelajaran dengan cepat dan tepat, senantiasa menganjurkan siswa dan menjalani pola hidup, dan serta senantiasa mengajarkan dan mengajak siswa untuk menjaga lingkungan dengan baik. Nasution (dalam suparlan, 2005:107) yang menyatakan bahwa seorang guru yang baik menguasai bahan pelajaran, bukan hanya sebatas aspek kognitifnya, melainkan juga nilai dan penerapannya bagi kehidupan manusia. Berdasarkan penelitian dan pendapat di atas, seorang guru pendidikan jasmani, olahraga dan kesehatan adalah menguasai pengetahuan kesehatan hal tersebut dikarenakan ilmu kesehatan merupakan kemampuan yang harus ada pada guru pendidikan jasmani, olahraga dan kesehatan. Selain menguasai pengetahuan kesehatan, seorang guru pendidikan jasmani, olahraga dan kesehatan senantiasa menjalankan pola hidup sehat.

\section{KESIMPULAN}

Setelah melalui proses yang cukup lama dan banyak, akhirnya didapatlah suatu kesimpulan yang menyatakan persepsi siswa SMA Negeri 3 Malang terhadap Profil Guru Pendidikan Jasmani, Olahraga dan Kesehatan tahun ajaran 2008/2009. Adapun kesimpulan dari penelitian ini dapat dijabarkan dalam lima aspek yaitu fisik, moral, hubungan sosial, kemampuan olahraga dan pengetahuan kesehatan.

Dari aspek fisik, diperoleh kesimpulan yang menyatakan bahwa persepsi siswa SMA Negeri 3 Malang terhadap profil guru pendidikan jasmani, olahraga dan kesehatan tahun ajaran 2008/2009 adalah berbadan ideal, senantiasa aktif bergerak pada waktu pembelajaran, berpenampilan rapi sesuai dengan situasi dan kondisi, serta senantiasa mampu menyesuaikan suaranya sesuai dengan situasi.

Dari aspek moral, diperoleh kesimpulan yang menyatakan bahwa persepsi siswa SMA Negeri 3 Malang terhadap profil guru pendidikan jasmani, olahraga dan kesehatan tahun ajaran 2008/2009 adalah tepat waktu dalam segala aktifitas, memberikan penilaian 
dan hukuman secara adil sesuai kemampuan dan kesalahan siswa (obyektif), menyusun rencana pembelajaran sesuai dengan kurikulum, dan senantiasa mengawasi semua siswanya selama pembelajaran berlangsung.

Dari aspek hubungan sosial, diperoleh kesimpulan yang menyatakan bahwa persepsi siswa SMA Negeri 3 Malang terhadap profil guru pendidikan jasmani, olahraga dan kesehatan tahun ajaran 2008/2009 adalah senantiasa melakukan pendekatan dengan semua siswa sama baiknya dan senantiasa berusaha untuk memahami semua masalah yang dihadapi siswa dan membantu mengarahkan siswa mencari penyelesaiannya.

Dari aspek kemampuan olahraga, diperoleh kesimpulan yang menyatakan bahwa persepsi siswa SMA Negeri 3 Malang terhadap profil guru pendidikan jasmani, olahraga dan kesehatan tahun ajaran 2008/2009 adalah mengerti, memahami, dan menguasai semua teknik permainan dalam olahraga, senantiasa mampu menjelaskan dan memberikan contoh berbagai keterampilan atletik kepada siswa, senantiasa mampu menjelaskan dan memberikan contoh berbagai keterampilan yang ada pada olahraga beregu kepada siswa, dan mampu menjelaskan dan memberikan contoh berbagai keterampilan yang ada pada olahraga perorangan kepada siswa.

Sedangkan dari aspek pengetahuan kesehatan, diperoleh kesimpulan yang menyatakan bahwa persepsi siswa SMA Negeri 3 Malang terhadap profil guru pendidikan jasmani, olahraga dan kesehatan tahun ajaran 2008/2009 adalah mengetahui dan mampu memberikan pertolongan pertama pada siswa yang mengalami kecelakaan pada waktu pembelajaran dengan cepat dan tepat, senantiasa menganjurkan kepada siswa dan menjalani pola hidup sehat, dan senantiasa mengajarkan dan mengajak siswa untuk menjaga lingkungan dengan baik.

\section{DAFTAR PUSTAKA}

Adrian. 2004. Metode Mengajar Berdasarkan Tipologi Belajar Siswa, (Online). 4drian@Pendidikan.zzn.com <4drian@Pendidikan.zzn.com> diakses tanggal 20 November 2008).

Arikunto, Suharsimi. 2006. Prosedur Penelitian Suatu Pendekatan Praktek. Jakarta: PT. Rineka Cipta.
Lewis, Ramon. 2004. Dilema Kedisiplinan. Jakarta: PT Grasindo.

Mulyasa. 2007. Standar Kompetensi dan Sertifikasi Guru. Bandung: Remaja Rosda Karya.

Rohmatika, Kanthi. 1998. Persepsi calon Mahasiswa Pendidikan Olahraga dan Kesehatan FIP IKIP Malang Jalur PMDK Angkatan 1998/1999 Terhadap Profil Guru Penjaskes SMU. IKIP Malang: Jurusan Pendidikan Olahraga dan Kesehatan.

Soelaiman, M. I. 1985. Menjadi Guru. CV Diponegoro.

Sondita, M. F. A. dan Burhanudin. 2000. Pelajaran Dari Pengalaman Proyek Pesisir Tahun 1997-2000. Bogor: Pusat Kajian Sumber Daya Pesisir dan Lautan IPB.

Suparlan. 2005. Menjadi Guru Efektif. Yogyakarta: Hikayat Publishing.

Tim Peneliti Balitbang Diknas. 2008. Makalah Pengembangan Model Pembelajaran Kecerdasan Kinestetik untuk Pendidikan Dasar. Jakarta: Departemen Pendidikan Nasional- PUSLITJAKNOV.

Tim Penyusun Kamus Pusat Bahasa. 2002. Kamus Besar Bahasa Indonesia. Jakarta: Balai Pustaka.

Walgito, Bimo. 2004. Bimbingan dan Konseling di Sekolah. Yogyakarta: Andi.

Wirjosantosa, Ratal. 1984. Supervisi Pendidikan Olahraga. Jakarta: Penerbit UI. 